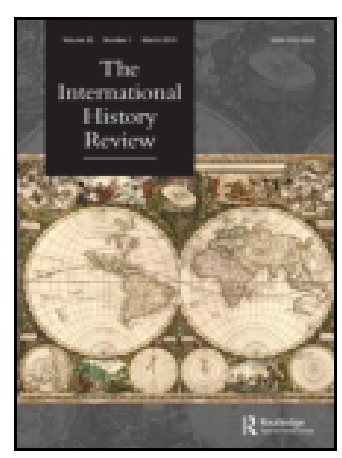

The International History Review

\title{
Exercise ALCORA: Expansion and Demise, 1971-4
}

\section{Filipe Ribeiro de Meneses \& Robert McNamara}

To cite this article: Filipe Ribeiro de Meneses \& Robert McNamara (2014) Exercise ALCORA: Expansion and Demise, 1971-4, The International History Review, 36:1, 89-111, DOI: 10.1080/07075332.2013.828638

To link to this article: http://dx.doi.org/10.1080/07075332.2013.828638

曲 Published online: 13 Dec 2013.

Submit your article to this journal $\pi$

Џلll Article views: 169

Q View related articles $\asymp$

View Crossmark data 


\title{
Exercise ALCORA: Expansion and Demise, 1971-4
}

\author{
Filipe Ribeiro de Meneses* and Robert McNamara
}

\begin{abstract}
Exercise ALCORA, launched in 1970, was a military understanding negotiated, in secret, by Portugal, Rhodesia, and South Africa. Between October 1970 and April 1974 there were regular meetings of the various ALCORA bodies, which had the effect of bringing closer the staff officers of the three armed forces. The military ties between the three countries were further deepened through the creation of permanent ALCORA planning and intelligence organisations, as well as dedicated military forces. This article examines ALCORA's trajectory, and the hopes deposited in it by its promoters, as well as its eventual demise in the wake of the Portuguese revolution of 1974. It pays close attention to the links between that trajectory and the changing security situation in southern Africa, notably in the Tete province of Mozambique, the source of mounting concern within the ALCORA establishment. The shortcomings of ALCORA are also highlighted, notably its failure to identify the greatest of all threats: Portugal's waning commitment to its colonial wars.
\end{abstract}

Keywords: Southern Africa; decolonisation; ALCORA; 1974 Revolution

In an earlier article, the origins of Exercise ALCORA were examined. ${ }^{1}$ ALCORA was found to be the result of a number of factors: a cold-war climate in which the West seemed to be on the defensive; the worsening military situation in the Portuguese colonies; a revision in South African military thinking (notably the development, by General Charles Allan Fraser, of a 'total threat' scenario ${ }^{2}$ ); and internal rivalries within the South African government. The aim of ALCORA was ambitious in that it sought to 'investigate ways and means of achieving a coordinated tripartite effort between Portugal, Rhodesia and the RSA with a view to countering the mutual threat against their territories in Southern Africa' ${ }^{3}$ The ties that bound the military staffs of the ALCORA countries - Portugal, Rhodesia, and South Africa - continued to strengthen in the years that followed, despite a number of issues, some of them serious, which remained contentious among their respective governments, and even among the wider armed forces. The objective of this article is to illustrate that strengthening, best exemplified by the creation of the Permanent ALCORA Planning Organization (PAPO), before moving on to examine ALCORA's demise in the wake of the Portuguese revolution of April 1974 - an event which, despite its enormous implications for Southern Africa - caught ALCORA operatives unawares. ${ }^{4}$ That the Portuguese revolution came as a surprise to decision-makers in Rhodesia and South Africa was, however, indicative of ALCORA's failings, and these too will be explored in this article.

*Corresponding author. Email: Filipe.deMeneses@nuim.ie 


\section{The international context}

During Exercise ALCORA's four-year lifespan, the international fortunes of the white-ruled states, closely linked to the cold war, ebbed and flowed. ${ }^{5}$ On the one hand, the US and UK electorates tacked to the right, electing Richard Nixon and Edward Heath. Nixon and his National Security Advisor, Henry Kissinger, were convinced that Africa's white-ruled states were likely to continue for the foreseeable future. Irritated by the anti-American attitude of black-run African countries, the Nixon administration, late in 1969, tilted marginally towards the 'white redoubt' with the implementation of National Security Study Memorandum (NSSM) 39 of late 1969, as was noticed by a South African observer. ${ }^{6}$ Edward Heath's Conservative Party government, meanwhile, lifted the arms embargo on South Africa ${ }^{7}$, showed considerably more understanding for Portugal ${ }^{8}$ and signed an agreement with Ian Smith's rebel government in Rhodesia in November 1971, although the deal eventually failed when the Pearce Commission reported its overwhelming unacceptability to the African population. ${ }^{9}$ Portugal seemed on the verge of receiving much more sympathetic treatment from the United States after it facilitated the US resupply of Israel during the 1973 Middle Eastern War. ${ }^{10}$ South Africa was actively pursuing a South Atlantic Pact involving like-minded Latin American countries, an idea making headway in $1969 .{ }^{11}$ The closing of the Suez Canal after the 1967 Middle East War and the growth of the Soviet Union's naval power increased the strategic importance of the Southern Africa for the West. ${ }^{12}$ From 1967, South Africa had also attempted to improve its relations with some of the African states. This outward policy was motivated by both what Pretoria believed to be common sense and the belief that regional bridge-building would enhance relations with the West. ${ }^{13}$ However, with notable exceptions in Francophone Africa and Malawi, the policy garnered little results. Simultaneously, the Soviet Union and China were stepping up their support for frontline states and liberation movements alike. ${ }^{14}$ The Soviet interest in Southern Africa, although modest in ambition ${ }^{15}$, was motivated by the opportunities provided by the perceived western tilt towards the white-run states and the need to block the Chinese, who were now bitter opponents. ${ }^{16}$ Sophisticated surface-to-air missiles were supplied to rebels in Guinea-Bissau in 1973 by the Soviets at Cuba's request. ${ }^{17}$ This greatly weakened the Portuguese position there and no doubt these game-changing weapons would have flowed to Angola and Mozambique, if not for the April 1974 coup in Lisbon. The flow of ever more sophisticated weapons was a major problem for the white-run states: from 1964-75 only France was still supplying South Africa with sophisticated weaponry. ${ }^{18}$ The gravest foreign threat to these embattled countries was considered to be China, particularly through the financing and building of the Tanzania-Zambia (TANZAM) railway, which threatened to break the white economic stranglehold over Zambia. On the battlefield, though, matters were ambiguous. A perilous situation in Angola at the end of the 1960s seemed to have been turned in Portugal's favour by the early 1970s. ${ }^{19}$ However, despite a stepped-up rhythm of Portuguese military operations, FRELIMO's insurgency became increasingly threatening in Mozambique. Its undoubted ability to hold territory in the Tete district threatened the showpiece hydroelectric project at Cahora Bassa, allowed for attacks into neighbouring districts, and had led, by 1972, to the revival of guerrilla activity by Zimbabwean liberation groups, who now had safer passage into their operational zone. It was this international context of mounting threat drove the ALCORA project. 


\section{The consolidation of ALCORA}

By the end of 1970 the basic architecture of ALCORA had been sketched. At the highest level stood the ALCORA Top-Level Committee (ATLC), which was to meet eight times over four years ${ }^{20}$; below it stood the ALCORA Coordinating Committee (ACOC), which oversaw the workings of subcommittees dealing with priority issues. These included intelligence, forward planning, logistics, transportation, and telecommunications. Meetings of its central bodies - the Top-Level Committee and the Coordinating Committee - began to occur regularly in 1971 , as did those of the lower-level subcommittees. ${ }^{21}$ There was a lot to get through; the fear of a conventional war in Southern Africa in the mid to long term led to a number of working papers which had to be constantly reviewed and revised, covering, for example, the means of securing safe communications and telecommunications, an estimate of the potential enemy's military strength, its vulnerable points (for aerial attack), and its dealings with the super-powers, as well as China, whose interest in Africa was becoming evident at this stage. ${ }^{22}$ The first meeting of the Coordinating Committee was held in Lisbon, in May 1971. Detailed instructions were prepared for all the subcommittees; thus, for example, Intelligence, singled out as the most important subcommittee, was told to 'study the documents produced by the Portuguese and South AfricanRhodesia Delegations in order that eventually a comprehensive jointly agreed paper on the threat may be produced.' From its first meeting there should emerge a 'preliminary document outlining the threat to Southern Africa', no longer than six pages. Such a document would then be updated at each meeting of the subcommittee, 'or when new intelligence dictates the revision or updating of the document as necessary'. The subcommittee should also 'establish the most appropriate channels to exchange intelligence, that is, any information of interest to other countries must be passed' and then, 'by whatever means necessary', it should be confirmed. ${ }^{23}$

ALCORA's foundation documents followed quickly. In 1972 the Psychological Action Subcommittee prepared PASC/11, detailing the 'psychological threat' to the ALCORA territories. ${ }^{24}$ In all-encompassing terms it noted: 'Adverse actions are designed to influence opinions, feelings, creeds, and, thus, the attitude and behaviour of friends, enemies or neutrals, in order to ensure or facilitate the securing of their interests in the ALCORA territories, and undermining those of the legally constituted governments. ${ }^{25}$ That same year the Command and Control Subcommittee (CCSC) produced document CCSC/9, outlining ALCORA's inter-armed forces cooperation systems. This document specified three types of international co-operation: Coordinated, Support, and Combined Operations. It further stated that in order for any of these operations to be carried out, inter-governmental approval was necessary. ${ }^{26}$ The Counter-Insurgency Subcommittee set to work devising a common doctrine, which might be inscribed in a single paperback volume, to be carried by officers in the field. So much paperwork was being generated, in fact, that secrecy became a paramount concern. At the third ACOC meeting, in Salisbury in April 1972, it was suggested that each country establish a secure library, where copies of all ALCORA documents be housed, reducing the security risk attached to delegates travelling with the required copies of Top Secret documents. ${ }^{27}$ Meanwhile, the aerial mapping of the Tete district in Mozambique (Operation Junction), seen as a priority action, began under ALCORA auspices.

Experience showed which Subcommittees were worthwhile and which ones could be sacrificed. One early victim was the Medical Subcommittee, whose death sentence 
was passed by the $3^{\text {rd }}$ ATLC meeting. Reorganisation also occurred at the level of the subcommittees devoted to aerial matters; three - the Aerial Planning, Air Defence, and Airfield Subcommittees - devolved into a single entity (still called Aerial Planning Subcommittee). This subcommittee complained that it lacked both intelligence on the aerial threat to the ALCORA territories - which had yet to be provided by the ISC - and a general strategy, which only governments could provide. ${ }^{28}$ This was a fundamental question, and one which the Portuguese delegation, led by Brigadier M. D. Neto, wanted to see noted in the minutes. The Portuguese then went on to state four measures that could not be excluded from the "strategic concept of the use of ALCORA forces':

(a) Systematic weakening of the Enemy elements participating in the revolutionary war, with special incidence over the guerrilla elements.

(b) Existence of an aerial dissuasion force, capable of preventive and retaliatory action.

(c) Existence of airborne means of intervention capable of operating, at a moment's notice, wherever their presence may be demanded;

(d) Active and passive defence of the vital points of our military and economic structure.

This was an early assertion of the need for a joint airborne intervention force, a concept whose importance would grow in time. Significantly, it was put forth not by the Portuguese Army, but by the Air Force; the two corporations' attitude to the conflict differed, and this rift would continue to grow until $1974 .^{29}$

\section{Intelligence successes and failures: the case of PAIO}

The first move from ad hoc arrangement to more permanent liaison structures came in the field of Military Intelligence, through the setting up of the Permanent ALCORA Intelligence Organization (PAIO), argued for by the Intelligence Subcommittee (ISC) from its very first meeting in June 1971. At the second meeting, in September of that same year, the subcommittee 'elaborated a detailed study into the creation of a Permanent Secretariat': a recommendation that was accepted by the Coordinating Committee, which passed it on to the ATLC along with the suggestion for disbandment of the Intelligence Subcommittee. The ATLC, meeting in December 1971, accepted in principle the creation of a Permanent Commission, but decided to refer the matter of the Subcommittee to the three national governments. The Subcommittee stuck to its guns and at its third meeting, in January 1972, recommended its own survival and insisted that the new body should be called a Permanent Secretariat, and not a Commission, whose work would aid the Subcommittee. Three months later, ACOC defended the use of the term Commission. ${ }^{30}$ Meeting in July, the Subcommittee reaffirmed its point of view that an Intelligence Subcommittee was needed, supported by 'a permanent body which continuously centralizes all of the complex and vast tasks of amassing and processing intelligence'. This was upheld by the $3^{\text {rd }}$ ATLC meeting. Rhodesia would house the new body although PAIO 'should eventually be located within the combined ALCORA headquarters, when this is established'. ${ }^{31}$ When created, PAIO ensured that the professionalism of ISC reports increased, as did the quality of the commentary on the raw intelligence. ${ }^{32}$ 
The document on threat assessment proved problematic, especially in relation to Mozambique. An early draft, ISC/2, was found wanting at the third meeting of ATLC. The Rhodesian delegation thought it unduly optimistic, and forced changes to the proposed wording, which henceforth warned of 'serious consequences should the situation in Tete not be reversed'. Nevertheless, the Intelligence Subcommittee stuck to its guns, producing ISC/3 the following month. This was seven pages long, and attempted to summarise the dangers facing ALCORA at short (until the end of the year) and medium (until the end of 1976) terms. The USSR was identified as the main menace. Moscow's threat was three-pronged. It secured aid to African states in order to increase its influence; it provided direct help to the 'terrorist organizations' and moral support for them at world gatherings; and it extended naval operations to encompass the Indian and South Atlantic Oceans. A second danger was Communist China, now a member of the United Nations; it too supported the 'terrorist organizations' and the OAU, especially when it came to a 'Joint African Force'. Beijing was determined to raise the issue of Namibia at the United Nations, to exploit the Tanzania-Zambia (TANZAM) railway to extend its influence over the countries involved, as well as Botswana, and to encourage 'terrorist offensives' in Angola and Rhodesia. The United Nations, 'subject to the influence of the communist and Afro-Asian majority', was another source of hostility to ALCORA, as was the Organization of African Unity (OAU), which could be expected to develop a common military force, something that, because of its 'inherent difficulties', would not be ready until the end of 1976 . In the meantime, it would strengthen the hand of the 'terrorist groups', while frontline states such as Zambia and Tanzania increased their military capability. It is certainly true to say that Chinese policy hardened after 1971 in support of the Mozambique Liberation Front (FRELIMO), especially after Samora Machel's visit to Beijing. ${ }^{33}$ In Malawi, Dr Banda's hand was weaker than before, it being possible that its support would vanish before the end of 1976. Finally, ISC/3 analysed the 'terrorist' threat. In Rhodesia the development of urban terrorism, aimed at the white population, was viewed as a possibility; some 'subversion and violence' was admitted in South Africa, alongside South-West Africa People's Organisation (SWAPO) incursions and mine-laying expeditions in South-West Africa. In Angola the expectation was that the situation would improve, while in Mozambique, finally, the situation was described as being under control, notably in Tete, and so 'it can be concluded that a deterioration of the situation is not foreseeable, unless FRELIMO receives considerable reinforcements. ${ }^{34}$ This assessment flew in the face of reality, and, as will be shown, since Tete was emerging as the key battlefront in Southern Africa.

In December 1972 the Portuguese Minister of Defence approved the ALCORA Countries Military Strategic Concept. ${ }^{35}$ This was defined as a 'global strategic concept' for Southern Africa - defined as the ALCORA territories, Botswana, Swaziland, Lesotho, and Malawi. 'Southern Africa' was, according to the document, a political, not a geographic, term; it therefore excluded the countries defined as 'neighbours': Tanzania, Zambia, Zaire, Congo, and Madagascar. The document pointed out that within the wider setting of the cold war, dominated by the threat of nuclear confrontation among the superpowers, 'international disagreements will probably be resolved through successive limited conflicts.' Southern Africa, abandoned by the West, and coveted by the Soviet bloc for its strategic and material importance, was a key battleground. The document argued that 'a joint plan against Southern Africa, to which Russia and China are committed, is already being 
executed.' It was a long-term venture, including important infrastructural commitments that might with time be used to underpin a conventional conflict. The ALCORA countries were not self-sufficient; they were dependent on raw materials (including oil), finished goods (including military equipment), and, 'especially as far as Angola and Mozambique are concerned, the additional human potential and further resources sent by the Portuguese metropole'. This meant that external lines of communication had to be kept open for Southern Africa to survive. Against such a threat, military preparation, as well as internal security, had to be stepped up: 'However, the ALCORA strategic concept for action will be meaningful only if it generates tripartite reaction to any aspect of the global threat, from the subversive already under way against each and every ALCORA territory - to a threat that might have conventional characteristics.' The document was confident that in the medium term (end of 1976), the ALCORA countries could handle threats even if China increased aid for an 'African Intervention Force'. The long-term forecast generated some concern: the situation might worsen to such an extent that the United Nations, dominated by unfriendly countries, would intervene in order to put an end to a dispute allegedly capable of endangering world peace. This is because African states, with Soviet or Chinese aid, might well have acquired the military technology required to cut ALCORA off from the rest of the world. The document concluded by setting out the six military objectives for ALCORA: eliminate subversive activity (by using 'military means to destroy terrorism wherever it exists and prevent its establishment in non-affected areas'); organise a strategic force, made up of mobile land forces and air power, to dissuade aggression and 'ensure a timely and efficient intervention'; develop an 'intense socio-psychological campaign' designed to win over the population of the ALCORA countries; develop an external psychological campaign, to demonstrate the importance of the struggle against the Communist bloc in the region to ALCORA's neighbours and the 'free world'; develop a better intelligence network, especially in the neighbouring countries, capable not only of detecting threats but also carrying out 'special operations'; and, finally, guarantee maritime communications, notably the Cape Route.

The publication of this document was welcomed by the $\mathrm{ISC}^{36}$, which expressed its complete agreement with the Strategic Military Concept as outlined. It added, however, that the ALCORA intelligence machinery was not in a position to establish the required network of agents, something that could only be done by the national intelligence services, not under ALCORA control. ${ }^{37}$ Intelligence services were not immune to rivalries and jealousies; the rift in South Africa between BOSS and Military Intelligence was notorious, and might well have played a part in the ISC's difficulties. The ALCORA Strategic Concept was also examined by the APSC ${ }^{38}$, which stated that the main strategic task - 'the elimination of terrorism' - would be hard to accomplish without each country having the required number and type of counter-insurgency planes, as outlined in earlier documents. Of great importance in the preparation for future conflict had been the holding of a paper exercise in the second half of 1972, long called-for, to test the effectiveness of the ALCORA structures as they had developed. ${ }^{39}$

\section{A combined headquarters}

At the $3^{\text {rd }}$ ATLC meeting, in June 1972, it was agreed that a combined ALCORA headquarters was desirable, since it 'would lead to greater efficiencies in the studies 
and labours at military level, while making it easier for the three Governments to raise ALCORA to a higher status'. The Command and Control Subcommittee (CCSC) drew up proposals, and subsequently the $4^{\text {th }}$ ACOC meeting agreed that ALCORA objectives could not be met without a permanent HQ with a planning staff attached, and perhaps permanent 'psychological action' staff as well. The $4^{\text {th }}$ ATLC agreed, subject to political approval. The $4^{\text {th }}$ ACOC and ATLC meetings considered a document entitled 'The Future of Exercise ALCORA'. The most likely threat to ALCORA was still seen as a conventional attack (by the OAU) as a humanitarian response to domestic disturbances in the white redoubt. Worryingly ALCORA, as it stood, would not be able to respond in time. Planning and operations had to be made more dynamic through a permanent HQ as large-scale joint operations had to be envisaged in a time of crisis. The $5^{\text {th }}$ ACOC meeting, in Lisbon, May 1973, examined the latest CCSC proposal for a Combined ALCORA Permanent Staff (CAPS), concluding that this should be instituted immediately as the nucleus of a future ALCORA Headquarters. The ATLC agreed that the ALCORA strategic concept could not work without a permanent body. ${ }^{40}$ This CAPS proposal formed the basis of a more ambitious creation when, at the $5^{\text {th }}$ meeting of the ATLC, the presiding officer, General van der Riet (SADF), reported that the South African and Portuguese Defence Ministers had agreed a Permanent ALCORA Planning Organization (PAPO), with Pretoria offering to house the new body and to furnish it with administrative services. ${ }^{41}$ PAPO's mission was 'to plan, coordinate and implement ALCORA issues as determined by ATLC and ACOC' ${ }^{42}$ Its duties were to accelerate the planning, co-ordination, and implementation of ALCORA matters, elaborate ALCORA doctrine and a policy of uniformity, coordinate and formulate contingency plans, take over the responsibilities of the subcommittees, and constitute a headquarters should combined operations be required. Alongside PAPO, it was considered that a hitherto dormant element within ALCORA, its Permanent Consultative Committee (PCC), would be activated, beginning in September 1973 in Lourenço Marques. The significance of the PCC was that it brought together the operations commanders of the three countries. One meeting eventually took place, but the $6^{\text {th }}$ ATLC meeting, in November 1973, suspended the PCC and decided that thenceforth the Portuguese ATLC delegation should include the Commanders-in-Chief for Angola and Mozambique. It was also agreed that ALCORA operational commanders should be able to meet whenever their mutual interest demanded it, but that a PAPO element should be present. All of this, of course, suggests some tension between staff officers and their counterparts in the field. On 12 September 1973, the ALCORA Defence Ministers met to approve the creation of PAPO. ${ }^{43}$

In October 1973, ACOC met in Salisbury. SADF Major General Clifton, PAPO's Director General, predicted that PAPO's Pretoria HQ would be ready in mid-November. ${ }^{44}$ By the end of the following month, at the $6^{\text {th }}$ ATLC meeting also in Salisbury, Clifton stated that Rhodesian and South African officers to be seconded to PAPO had all been named, but only two Portuguese. The PAPO premises were to be ready by the end of the month, while a document entitled 'Mission, Organization and PAPO functions' had been produced and was at the disposal of the ATLC for approval. PAPO, Clifton added, would be ready to begin its regular work on 7 January, and it was to be hoped that the full complement of Portuguese personnel would be appointed at the start of 1974. One of PAPO's drawback was that secrecy became harder and harder to ensure; the pressure for public disclosure of ALCORA 
mounted at this time but was resisted by Portugal, afraid of being portrayed internationally as unable to preserve order in its 'overseas provinces'.

\section{The war in Tete}

The evolution in Exercise ALCORA must be set against the background of the evolving military situation in the Portuguese colonies. The north-western Mozambican province of Tete was a major preoccupation. Hitherto neglected from a developmental point of view, it was now the setting for the most grandiose Portuguese building project in Africa, the giant Cahora Bassa Dam on the Zambezi River. Cahora Bassa was set to transform the landscape, through the creation of an enormous lake, and generate more power than Mozambique could hope to consume. It was funded in part by South African investors, and its electricity had to be exported across the whole region in order for it to be financially viable. Road and rail links were improved in order to allow for the construction to go ahead, and a virtual city established for the international workforce, whose protection was a paramount concern for the Portuguese. A vast but vulnerable network of pylons and electrical cables had to be put in place to allow for the distribution of the power generated. It was hoped that the dam would begin operations at the end of 1974.

Just as 1970 had been the key year in the development of Exercise ALCORA, so too had it been the key year for the war in Mozambique. A new Portuguese military commander, General Kaúlza de Arriaga, took over the defence of the province. A Salazar loyalist, Kaúlza saw the war as part of a Sino-Soviet expansionist drive and believed in a successful military outcome. ${ }^{45}$ The overly optimistic Kaúlza was determined to take the war to FRELIMO on its chosen territory in the north-east district of Cabo Delgado. The largest Portuguese military operation of the colonial wars, codenamed Nó Górdio (Gordian Knot) was unleashed in July, involving as many as 8,000 Portuguese and locally raised forces, the Grupos Especiais. FRELIMO survived the offensive, its forces retreating northwards to safety in Tanzania. It also expanded its area of operations, despatching guerrillas to both the neighbouring Niassa district and the strategically vital Tete district, where the war would be won and lost. Confronted with a war on a larger scale, the Portuguese reacted by drafting an ever larger number of Africans into their army, while rounding up more and more of the population into protected villages, or aldeamentos. By 1971, Tete had become not only FRELIMO's principal front, a highway into other districts of Mozambique, but also of crucial importance for Zimbabwean nationalist organisations which used it as a point of entry into Rhodesia. Tete was, in this respect, far safer than the Zambia-Rhodesia border, along which Salisbury's forces were backed by a heavily armed South African police detachment. ${ }^{46}$

At the end of 1971, the Odell committee, limited to South African and Rhodesian defence officials, was established to review the deterioriating situation in the Tete district. ${ }^{47}$ The tone and language of its report reflected a growing disquiet about Portuguese tactics, the threat from the guerrila movements and the growing threat of Communist China. The committee members wanted to bring to the notice of their governments, as a matter of urgency, the imminent danger to the security of Southern Africa. Such was the deterioration of the Portuguese position in Tete that the Odell Committee argued that military liaison was not enough: the "potential danger' required bilateral meetings between Smith and Vorster, 'as a prelude to a 
meeting attended by them and the Prime Minister of Portugal'. ${ }^{48}$ It is remarkable that such discussions were occurring outside the existing ALCORA structures.

Given their doubts about the efficiency of the Portuguese Army, Rhodesia and South Africa identified the ability to operate freely in Mozambique as a priority. Licence was initially given by the Portuguese to Rhodesian forces entering Tete, in hot pursuit or for lengthier stays, but this was later revoked after Spanish missionary priests denounced the human effects of this intervention, notably the Mucumbura massacre. ${ }^{49}$ The issue generated severe tension between Rhodesians and Portuguese, evident at a meeting with the Rhodesian military leadership hosted by General Kaúlza de Arriaga and his staff at Kaúlza's Nampula headquarters on 4 August 1972. The Rhodesians, headed by Air Marshal A. O. G. Wilson, spoke of a 'marked deterioration of the security situation outside Rhodesia's borders', whose impact would soon be felt in Rhodesia itself. Rhodesian intelligence indicated that three enemy organisations, the Zimbabwe African People's Union (ZAPU), the Zimbabwe African National Union (ZANU), and the Front for the Liberation of Zimbabwe (FROLIZI), were present in Tete:

Rhodesian Forces would like to be able to take pre-emptive action against Rhodesian terrorist presence in the Tete District thus losing no opportunity to forestall their plans. However, this was not possible as General de Arriaga had recently withdrawn the Transborder Operations Agreement which permitted the Rhodesian forces to attack elements of ZAPU and ZANU in the Tete district.

Making possible this expansion of anti-Rhodesian activity was the 'Portuguese troop shortage'. The desired aim of the Rhodesian delegation was to obtain carte blanche 'to react immediately as opportunity presented itself' ${ }^{50}$ Kaúlza de Arriaga was not keen on the idea: he argued that the Cahora Bassa reservoir, once filled, would restrict access to Rhodesia from the Tete district; that the Portuguese were increasing their troop levels in the area, and improving communications; and that previous Rhodesian actions had led to the killing of civilians, and had been exploited by the common enemies of the two countries. The Spanish missionaries who had denounced the Mucumbura killings were now awaiting trial in Lourenço Marques; further Rhodesian actions before or during the trial would be exploited by the priests' defence: 'As the $\mathrm{C}$ in $\mathrm{C}$ he would have liked Rhodesia to help but he was subjected to enormous political pressures.'

The continued level of concern was demonstrated in a letter from Ian Smith to his Portuguese counterpart, Marcello Caetano, on 21 August, to be delivered personally by Central Intelligence Organization director Ken Flower. ${ }^{52}$ Smith wrote:

The activities of FRELIMO have been steadily increasing in the areas immediately adjacent to our common border and it is known that members of Rhodesian African terrorist groups operating from Zambia are taking advantage of this situation. They now find it easier to infiltrate into Rhodesia from Mocambique [sic] than directly across the Zambia-Rhodesia border.

The fact that FRELIMO had recently advanced into the Vila Pery area, to the south of Tete, only added to the sense of urgency. Smith also expressed his disappointment over the fact that General Sá Viana Rebelo, the Portuguese Minister of Defence, had met P. W. Botha (see below) while in Mozambique but not his Rhodesian counterpart, Jack Howman: 'In Southern Africa the interests of 
our three countries are indivisible and I believe that we should all ensure that we lose no opportunity of furthering our mutual cooperation.' Still, Smith offered to visit Caetano in Lisbon; it had, after all, been eight years since he had met Salazar, and 'so much has happened since then that there would be every justification for the two of us to meet as soon as it could conveniently be arranged. ${ }^{53}$ Smith did indeed visit Portugal early in October 1972, his presence in Lisbon being explained as a necessary component of a holiday, which included a stay in Madeira. ${ }^{54}$ All of this raises the possibility that all this Rhodesian pressure for more aggressive action (and the right to act independently in Mozambique) was a catalyst in the Wiriyamu Massacre in Tete in December 1972 by Portuguese troops. This foreign pressure might be usefully added to Reis and Oliveira's conclusion that the massacre stemmed from a successful provocation strategy by FRELIMO insurgents, increasingly aggressive Portuguese resettlement, a failure of intelligence and, lastly, Arriaga's new operational approach, which 'emphasized more kinetic search and destroy airborne operations and/or a discriminate killing of populations seen as irretrievably on the side of the insurgents'. ${ }^{55}$

The political damage to the Portuguese cause from too close a contact with the Rhodesian and South African regimes was enormous, since they embodied an absolute contradiction of Portugal's avowed desire to construct a multi-racial society. ${ }^{56}$ Still, pressure for a restoration of Rhodesia's right to intervene in Tete was immense, and eventually paid off - but only because the Portuguese found themselves unable to halt the insurrection in the district. After the vital Zambezi River line had been breached, all that the Portuguese could hope for was that FRELIMO's actions would be easier to control once the Cahora Bassa lake had begun to fill up. Early in 1974 the white population of two distant cities, Vila Pery and the key port of Beira, increasingly threatened by Tete-based FRELIMO units, erupted in protest against the army's inability to control the situation. ${ }^{57}$ Similar protests occurred in Nampula, this time aimed at Catholic priests, after the local bishop had defended Mozambique's independence, based on the Church's adhesion to the principle of self-determination, in a pastoral letter on 10 June. $^{58}$ Tete increasingly preoccupied influential Rhodesians and Portuguese, with the idea being mooted that 'the only solution was that of establishing a joint command': a Portuguese/Rhodesian partnership, with South Africa providing material and financial aid. ${ }^{59}$ As an expression of this mounting concern over Tete, Ken Flower visited Portugal some two weeks before the April revolution to meet with the Defence Minister. Rhodesia, the Central Intelligence Organization (CIO) director pointed out, had been considering the possibility of sealing off the Mozambican border, an immense undertaking; it would be easier, it had been concluded, to establish a line in Mozambique - such as the Zambezi River, from Zumbo, through the Cabora-Bassa lake, until the Indian Ocean - wherein all three countries could concentrate their military efforts. Simultaneously, they should sponsor the continued development in Mozambique of the Flechas, the fearsome force developed in Angola by the Polícia Internacional e de Defesa do Estado/Direç̧ão-Geral de Segurança (PIDE/DGS), Portugal's secret police, initially composed of Bushmen and later expanded to include captured nationalists. ${ }^{60}$

Fighting in the district can be seen as the catalyst for change within ALCORA, transforming it from an agency designed to deal with a medium-term conventional threat to one whose remit included the war actually being waged. The $6^{\text {th }}$ ATLC meeting directed the nascent PAPO organisation to produce a 
document on 'The Elimination of Terrorism in Southern Africa'. Given the everworsening situation in Tete, this was not surprising. Reporting to the ATLC in June 1974, South African Defence Force (SADF) Major General Clifton, still in charge of PAPO, pointed out that he and his staff had started from scratch on this task: 'Our interpretation of your directive was that you required us to recommend a realistic strategy and practical plans to defeat terrorism. Consequently, the theme of this study as it developed, was the need for combined offensive action to gain the initiative.' Envisaged outcomes included operations in the Zambezi Valley and simultaneous attacks on terrorist bases in neighbouring countries. While this document was being elaborated, the old Sub-Committees briefed PAPO on their business before disbanding; eleven such sessions were held in the first months of $1974 .^{61}$

\section{A permanent ALCORA military force}

'The Future of Exercise ALCORA' mentioned, as alluded to above, the need for closer integration of the ALCORA armed forces in order to undertake large-scale combined operations. These would best be handled by an ALCORA Strategic Force (ASF), a mobile military reserve, part of it airborne, which could be deployed at short notice to a given trouble spot. The matter was discussed at length at the $5^{\text {th }}$ ATLC meeting, which recommended the creation of a working group to assess the matter and draft terms of reference for the CCSC. In these terms of reference, the working group urgently sought a study by the CCSC and the rapid creation of the force, which could be employed either against 'terrorism', whose elimination was confirmed as priority, or a conventional threat, should it arise. An initial estimate put this at a battalion, with air support, to be in place by the end of 1974, and an airborne brigade, with the required air support, to be ready by mid to late 1975; this was an open-ended military commitment, whose strength might continue to grow in accordance with evolving needs. The proposed force contained a significant paradox: it could only serve to dissuade if it was made public, but the political will to 'go public' on the reserve, and the ALCORA mechanisms behind it was not, as we have seen, present in Portugal. The $6^{\text {th }}$ ATLC meeting saw Rhodesia make the strongest yet link between ALCORA and the on-going war against 'terrorism', which had to be defeated and not just contained: as a result, PAPO was instructed to review the work already carried out and to 'elaborate an appraisal of the situation, recommending plans for the best way of eliminating, immediately, terrorism from Southern Africa'. ${ }^{62}$ Not everyone in the Portuguese armed forces agreed with its creation, since not everyone believed that a military victory was possible. General Francisco Costa Gomes, by late 1973, was falling into this category. In an opinion written that month, Costa Gomes, at that time Chief of Staff of the Armed Forces, took the view that this permanent force, as proposed by ALCORA, would damage the operational capabilities of the badly stretched Portuguese defences. ${ }^{63}$ Costa Gomes played for time, arguing that it would be prudent to establish 'a certain number of principles and rules which the ASF should obey in the organisation, equipment and training of its units'. Costa Gomes ruled out completely the contribution, by Portugal, of helicopters to the force's aerial component, and stressed the need for an ALCORA aerial retaliation force, as well as a surface-to-air capability, areas in which South Africa could be expected to take the lead. 


\section{ALCORA's shortcomings}

We have already considered the workings of the Odell Committee, which met behind the backs of the Portuguese. Significantly, the Portuguese and South Africans also kept matters beyond the knowledge of the Rhodesians. In July 1972, the two countries' Defence Ministers met in Lourenço Marques. A variety of issues was naturally discussed. The final substantive issue was the 'inclusion of Rhodesia in the present meeting's affairs'. P. W. Botha stressed Rhodesia's importance to the defence of Southern Africa, and pointed out that collaboration with Salisbury should be wider than just ALCORA-related questions. Sá Viana Rebelo, while agreeing with Rhodesia's importance, replied that there was no need to inform Salisbury of the creation of a secure communications link between Pretoria and Nampula 'given the secret nature of the matters to be handled'. And when Botha asked if he could inform the Rhodesians of the discussions surrounding the Tete district, which concerned them directly, General Kaúlza de Arriaga, also present, complained of the brutality of the Rhodesians when allowed to operate in Portuguese territory. He added that in future, 'operations on national soil will always be carried out by our troops, who will force the enemy to move into Rhodesia, where that country's forces can then eliminate it. ${ }^{64}$

ALCORA was never able to smooth out the relationship between Portuguese and Rhodesian armed forces, nor to overturn the situation in the Tete district, which continued to worsen despite Kaúlza de Arriaga's assurances, and which became the main threat to Rhodesia's security, notably after the closure of the border with Zambia in January 1973. The US Consul in Lourenço Marques was well aware of these tensions between the Portuguese, who 'generally believe they know great deal more about counterinsurgency' than the Rhodesians and the South Africans, and the latter two groups, who frequently made 'thinly veiled suggestions they could run Mozambique war better than "slack", "inefficient" Portuguese'. ${ }^{65}$ At a regular tripartite meeting of the intelligence services, held in Lisbon in September 1973 outside the scope of ALCORA operations, with General Van Den Bergh of BOSS, Ken Flower of the CIO, and Major Silva Pais of the PIDE/DGS present, it was concluded that 'the situation in Mozambique is such as to cause deep worry to the South African and Rhodesian governments. It has been suggested that there is a need to re-examine the concept of joint operations, particularly in the common border areas, especially as far as the Tete district is concerned. ${ }^{66}$ It was also agreed that the Flechas experiment had to be extended - in other words, that the PIDE/DGS should take over more of the fighting, at the expense of an army which was increasingly distrusted by its supposed allies. The report on the situation in Mozambique, presented by the Portuguese secret police, was indeed worrying; in the Tete district FRELIMO now felt sufficiently confident to attack in large units of 100 200 guerrillas, as well as to employ heavy weapons, such as the $122 \mathrm{~mm}$ rockets, south of the Zambezi River. An urban guerrilla campaign in Tete town itself could not be ruled out. Worse still, FRELIMO had met with little resistance as it moved south into Vila Pery district; in one year, its fighters had moved $200 \mathrm{~km}$ into Portuguese territory with no strain on their supply chain - this while making inroads into the Beira district as well, with considerable impact on the morale of the civilian population, white and black. Two months later, at the $6^{\text {th }}$ ATLC meeting in Salisbury, the delegates listened to a report by a Lieutenant Colonel Parker of the Rhodesian Army regarding his corporation's on-going operations. The presiding officer, Lieutenant General G.P. Walls, explained 'that the Rhodesians' operations in Mozambique were being carried out with the complete approval of General Basto Machado (the Portuguese 
Commander-in-Chief) and that the co-operation between the two countries was very good'. ${ }^{67}$ That these operations, not specified in the minutes, had not resolved the problem was evident from the rest of the meeting; discussing the possibility of an 'AntiTerrorist Reserve Force' (ATRF), the Rhodesians argued that terrorism was being contained, not eliminated, and that the time had come to co-ordinate efforts in order to eliminate terrorism in southern Africa: a stance which led the ATLC to charge PAPO with drawing up plans for precisely such an action.

Another dispute between Portugal and Rhodesia was related to the January 1973 closing of the Rhodesia/Zambia border, carried out by Ian Smith's government without consultation with the ALCORA countries. Not only were the Portuguese annoyed by this unilateral measure, they actually profited from it, offering - to Salisbury's great annoyance - to accommodate extra cargo to and from Zambia on their railways. ${ }^{68}$ In June 1973 W. M. Knox, Rhodesia's 'accredited diplomatic representative in Lisbon', delivered a personal message from Smith to Caetano precisely on this point; the Rhodesian Prime Minister noted that 'criticism of Portugal apparently condoning Zambia's action' was growing in his country; many were now 'saying that our Portuguese friends are losing sympathy for us'. Smith was especially annoyed because the white countries' control of Zambia's rail links would end in two years' time, with 'the completion of the Tanzam Railway'. ${ }^{69}$

One final episode demonstrates ALCORA's shortcomings as a credible deterrent. Over the course of 1973, Portuguese preoccupation with Zairian intentions began to grow. In March, Marcello Caetano, meeting US Assistant Secretary of State for African Affairs David D. Newsome, mentioned the presence of some 40,000 Chinese in Tanzania, adding that 'Chinese in large numbers would shortly be coming to Zaire. ${ }^{70}$ According to the monthly ALCORA intelligence bulletin for February/March of that year: 'Mobutu stated that his meeting in Peking with Mao Tse Tung had been very successful and that China and Zaire would now "lead the Afro-Asian world". 71 Caetano's denunciation in a December radio 'fireside chat' of the removal of Portuguese immigrants from border areas of Zaire led the US Embassy in Lisbon to conclude that it probably presaged a substantial increase in Zaire-based insurgent activity in Angola. ${ }^{72}$ Portuguese fears mounted, troop levels were reviewed, and in February 1974 the Commander in Chief of the Portuguese forces in Angola, General Luz Cunha, met the South African military leadership, headed by Admiral Biermann in Capetown to discuss "the latent threat of invasion on North of Angola and Cabinda by the "Republic of Zaire" Armed Forces and in support of subversive Organization "FNLA". ,73 The whole process was given a codename, 'Operação Stop'; it culminated in the enormous loan (150 million rands) granted to Lisbon by Pretoria on 8 March. Half of this was spent in the days that preceded the 25 April revolution, some of it being used to purchase, via Israel, highly sophisticated weaponry, including the French-designed Crotale surfaceto-air missile system, presumably to shoot down the Mirage fighters which France had recently sold to Zaire (although the Portuguese were also eager to deter possible aerial attacks against Guinea). ${ }^{74}$ This flurry of activity, however, marked as it was by direct contact among politicians and leading officers, took place outside the confines of ALCORA.

\section{Revolution in Portugal}

On 25 April 1974 the Movimento das Forças Armadas (MFA), made up essentially of mid-ranking officers with African experience, deposed Marcello Caetano and 
seized power in Portugal. Capitalising on the movement's lack of an obvious leader, General António de Spínola, respected by the revolutionary officers for his recent break with the Caetano regime, moved quickly to be named President of the Republic - but his conservatism, notably on colonial issues, quickly put him at odds with the broad mass of the MFA. International observers were caught off-guard by the coup; this applied especially to those from the ALCORA countries. Indeed, it was the possibility of an ultra-right wing which preoccupied the South Africans at the time ${ }^{75}$; their Ambassador at Lisbon was sceptical about the actions of any leftwing opposition. ${ }^{76}$ Most important, in his eyes, had been the publication of Spínola's book Portugal e o Futuro. Spínola had, over many years, craftily constructed a public image of competence and determination. Building on his experiences in Angola and, more importantly, Guinea, he now announced that the war could not be won by military means alone, and advocated a federal solution to the colonial problem. Copies of his book flew off the shelves. General Costa Gomes, Spínola's commander, had sanctioned the publication of the volume; wary of an outright confrontation with the country's most senior officers, but asked to remain at his post by President Américo Tomás, Marcello Caetano was caught in a bind. After some hesitation Caetano spoke on overseas policy in the National Assembly on $5 \mathrm{March}^{77}$, and then orchestrated a ritual show of obedience by the officer corps that not all could stomach. Spínola and Costa Gomes refused to attend, and were dismissed from their positions. Spínola's post, which had been created for him, was extinguished; Costa Gomes' role, significantly, was taken over by General Luz Cunha, who had been overseeing 'Operação Stop' in close conjunction with Pretoria. The matter seemed, to Pretoria, to have been resolved in Caetano's favour.

If ALCORA's plan for a military solution to the crisis was unrealistic, then so too was Spínola's view of a federal 'Lusitanian Community', intended to rest on the principle of self-determination of all 'Portuguese', be they Europeans, Africans, or Asians. For a time, non-MFA officers, such as those involved in ALCORA, believed that Spínola might succeed in twinning a continued commitment to the war with the search for a political solution. The truth, however, was that no one else viewed this as viable, especially not the nationalist movements and their international backers, be it in the frontline states, the Communist bloc, or the West. Their wishes for an immediate decolonisation were matched by the aspirations of the bulk of the Portuguese armed forces still in Africa. But it would take the revolution and some three months' worth of equivocation in its wake to make the army's intentions clear. As a result, ALCORA remained in place and the $7^{\text {th }}$ ATLC meeting went ahead, in Pretoria, from 24 to 28 June. It was not yet clear how Portuguese policy in Africa would evolve, since the power struggle between the MFA and President Spínola was reaching its peak. The Portuguese delegate, General Basto Machado, had been Kaúlza de Arriaga's successor in Mozambique and was therefore well acquainted with the situation in that territory. The rest of the Portuguese delegation had a long history of ALCORA business. ${ }^{78}$ There was an air of unreality to proceedings, given the situation in Portugal. Chairing the meeting, South African Chief of Staff General R. F. Armstrong stated, in his opening address, that the major task of ALCORA and the reason behind PAPO's creation - was the elimination of terrorism in Southern Africa. As we have seen, this was a dramatic departure from ALCORA's early concerns with conventional warfare. Basto Machado replied that 'the Portuguese delegation was prepared to work with the maximum efficiency and co-operation that the present circumstances allowed.' This was hardly a vote of confidence, but another 
ALCORA veteran, Rhodesian delegate Air Marshal McLaren, could not contain his enthusiasm: 'This ATLC meeting was an historic occasion in that it was the first to be held in the ALCORA Headquarters - PAPO.'

With the meeting under way, the limitations on the Portuguese quickly became obvious. Press releases regarding ALCORA were out of the question; it would be difficult to fill the remaining vacancies in $\mathrm{PAPO}^{79}$; and, given the circumstances in Angola and Mozambique - but especially given the circumstances in Portugal, where the government and the parties were at war over the course of colonial policy - it would be 'difficult at this stage to plan for the elimination of terrorism'. Moreover, given the international situation, it was 'undesirable to consider any joint action by ALCORA within Mozambique at this time'. Portugal would not renege on the commitment to prevent her territory from being used as a base for attacks on other countries, but such a commitment demanded a continuation of military control over the areas concerned which could not be guaranteed indefinitely. The prospects for ALCORA were, in other words, bleak at best, but the other delegations seemed deaf to Lisbon's predicament. The Rhodesians, for example, re-emphasised the new view that 'the main object of ALCORA was the formation of forces to combat terrorism', an aim essential to Rhodesia's survival: in order to guarantee this, 'it was vital for military operations to continue into Mozambique.' But for the Portuguese, even 'hot pursuit' was now becoming problematic; there might come a time when the Portuguese were no longer in political control, even if they remained in military control, and in such a situation hot pursuit would not be allowed.

The pressure the Rhodesians were under was evident again in their insistence on the continuation of studies regarding the MSF and the ATRF, attributed a high priority in previous tripartite government meetings, but totally dependent on South African resources for their creation. As their delegates put it: 'ALCORA must have a plan.' The Portuguese were quiet on the issue, the South Africans sceptical: 'The three nations should so plan and develop their own forces so that when a situation develops which requires joint action, each nation will have the tools to do the job.' This, of course, made a mockery of ALCORA, and the Rhodesians were quick to point it out that their country 'was fighting for her survival'. Their appeal, surprisingly, had an effect. The ATLC issued a directive to PAPO which stated, once again, that 'ALCORA stands for a tripartite effort between the ALCORA nations to cooperate in military matters, with the prime aim of eliminating terrorism where it may exist, in the ALCORA territories. ${ }^{80}$ PAPO was thereby charged with preparing a study 'to determine how best to defeat terrorism in Southern Africa by joint action'. It was recognised, nevertheless, that this PAPO study, due on 31 August, depended on the co-operation of national staffs, who were invited to share their information fully with PAPO. Routine administrative matters were also pursued by the meeting, with new documents being approved and others reported on; it was agreed, pending approval, that the 8th ATLC meeting should be held, of all places, in Lisbon, from 18-22 November. In the event, the meeting occurred earlier than scheduled, on 14-15 October. The political situation in Portugal was nebulous. Spínola, unable to get his way over Africa (a date for Mozambique's independence, and interim government arrangements, had been negotiated with FRELIMO), and worried by the leftist drift of the country, had resigned, being replaced as President by the more pragmatic Costa Gomes. The well-organised Portuguese Communist Party was in the ascendancy; one of its sympathisers, Colonel Vasco Gonçalves, headed the government. The ALCORA meeting was chaired by General J. A. Pinheiro, Assistant to 
the Chief of Staff of the Armed Forces. Walls and Armstrong represented, respectively, Rhodesia and South Africa. This time there were no equivocations. From the onset Pinheiro announced that 'the future of ALCORA cannot remain in its present form.' Pinheiro insisted that all deals regarding hot pursuit of suspects were off as a result of the Lusaka agreement with FRELIMO. ${ }^{81}$ It was also the case that the Portuguese believed FRELIMO and the Angolan nationalist movements suspected the existence of military deals between Portugal, Rhodesia, and South Africa, which, it was feared, would derail attempts to carry out a peaceful transition in the soon-tobe ex-colonies: 'The Chairman made clear the impossibility for Portugal of allowing any military activity within the ALCORA concept.'

According to Pinheiro's account, Portugal had not entirely forgotten the interests of its ALCORA partners: 'Portugal tries and will always try to convince FRELIMO about the interest of their cooperation with the R.S.A. and Rhodesia'; the former 'terrorists', now partners in power in Mozambique, had already, it seemed, 'modified their initial position towards the two countries', especially South Africa. The case of Angola, of course, was different, given the number of liberation movements and white settlers; to bring about a peaceful solution would require time, a solution for the other colonies, and economic/financial support. It was this support which the ALCORA partners could now make available to Portugal, if indeed they desired a peaceful Angola.

While the South African delegation's comments were brief and guarded, the Rhodesians' were of a different mood. Hot pursuit, they argued, was a necessity; it was a right enjoyed by every country, and Rhodesia, while establishing contact with FRELIMO via Portuguese officers, would continue to engage in such military action against ZANU. They also alleged that FRELIMO, by appearing better disposed towards South Africa, was engaging in an 'age old method of separating good friends'. The Portuguese replied that military co-operation was now out of the question. As for ALCORA, it could not 'continue under that name and aims'. This did not mean that the countries involved could not be friends, and Portugal could serve as an interlocutor with FRELIMO; as for the officers based in PAPO, they could remain in Pretoria, 'but under a different guise'. The South Africans were under no illusions: what mattered now was considering what should take ALCORA's place. As the minutes show, 'it was decided that each delegation would consider separately what form of agreement it was now possible to reach.' This led eventually to a brief document, little over a page long, entitled 'Agreements as to future cooperation'. This extended to intelligence exchanges 'related to the maintenance of peace and security in Southern Africa' and to 'technological research and development', as well as the promotion of 'goodwill, understanding and cooperation' in Southern Africa. The document also committed Portugal to 'persuade' the emerging Mozambican and Angolan authorities to deny their territory to 'terrorist organizations', and to bring their own support for SWAPO to an end. There should be continued meetings at ATLC or 'even higher' level, but 'the code name ALCORA is to be dropped and future cooperation will continue under a new codename'. As for PAPO, it would 'cease to exist from 31 October 1974'.

\section{Conclusion}

ALCORA was not the answer to the enormous difficulties facing the 'white redoubt' in southern Africa: far from it, in fact. The three constituent parts were simply too 
far apart in their past history and future outlook to be able to work together, whatever a relatively small group of staff officers might have hoped for. This was obvious from the start: Portugal remained a European country, whose economy, for all the efforts being made in Africa, was geared towards trade with the European Economic Community (EEC) and European Free Trade Area (EFTA), to which it belonged. Its political and economic elites did not want the country to be a pariah, relying totally on the links with the empire and the ALCORA partners. The lure of European integration was powerful, as was growing frustration with the human and material cost of the African wars. Hence the difficulties in making ALCORA better known, despite the dissuasive effects of going public with the Exercise and components such as the permanent reaction force. Meanwhile, South Africa's political leadership, divided over issues of tactics and personality, did not yet believe in the possibility of its demise: the ALCORA partners were seen as useful, but ultimately expendable. For Rhodesia, very much in the front line, ALCORA was a practical expedient, a way of reaching a desired end: the military defeat of its existential enemies, the Zimbabwean liberation movements. Nothing else mattered.

There were other, more practical difficulties affecting the development of ALCORA into an entity capable of transforming the situation in the region. Contact between the ATLC and front-line commanders was infrequent and poor. The PCC was envisaged as the mechanism which would ensure these commanders a say in the running of ALCORA, and its importance was recognised by the ISC but not, it seems, by anybody else. It never operated properly, and was eventually subsumed into the ATLC, but too much time had been wasted in the process. It was also the case that the gathering and dissemination of useful intelligence, arguably ALCORA's most basic mission, proved to be a difficulty. The ISC was always independentminded and difficult to control; PAIO, designed to help it, was very limited in scope and means. In any case the ISC and PAIO were focused exclusively on threats to ALCORA from the outside. This was behind its most spectacular failure: the inability to see the trouble brewing within the Portuguese Army. Exhaustion with the war; the inability of the political leadership to arrive at a negotiated solution to the crisis; mounting international criticism: all combined to turn the Portuguese Army from a mainstay of ALCORA into the instrument of its demise.

\section{Notes}

1. F. Ribeiro de Meneses and R. McNamara, 'The Origins of Exercise Alcora, 1960-1971', International History Review (2013).

2. Especially important is Fraser's document, 'Review of the Campaign in East and South East Angola 1968 to End of January 1970', a copy of which can be found at [Paço de Arcos,] A[rquivo da] D[efesa] N[acional], S[ecretariado] G[eral da] D[efesa] N[acional], U.I. 6967.

3. [Pretoria] S[outh] A[frican] N[ational] D[efence] F[orce] A[rchive], HSI Groep 8 Houer 159 LG-INT-6-1-1, Hoof Van Veredingataf to die vise-konsul, Luanda, 29 Nov. 1972, 'Exercise Alcora Military and Naval Attaché, Lisbon'.

4. While aspects of co-operation between the white-governed States has generated a good deal of scholarly and non-scholarly literature, most notably on sanctions-busting, ALCORA is rarely given detailed coverage. See for instance recent archive-based assessments such as A. S. Mlambo, "We Have Blood Relations Over the Border": South Africa and Rhodesian Sanctions, 1965-1975', African Historical Review, xl (2008), 1-29; C. R. W Dietrich, "A Climate of Collaboration": The Rhodesian Oil Embargo and Portuguese Diplomacy in Southern Africa, 1965-1967', Itinerário - Leiden, xxxv (2011), 
97-120; G. Stone, 'Britain and Portuguese Africa, 1961-65', The Journal of Imperial and Commonwealth History, xxviii (2000), 169-92; and S. Onslow, 'A Question of Timing: South Africa and Rhodesia's Unilateral Declaration of Independence, 1964-65', Cold War History, v (2005), 129-59. Even those who participated in ALCORA seem to have remained extremely secretive: there is an allusion to it in K. Flower, Serving Secretly: An Intelligence Chief on Record. Rhodesia into Zimbabwe 1964 to 1981 (London, 1987), 140. However, I. Smith, Bitter Harvest (London, 2008) does not mention it, nor does H. Hamann, Days of the Generals (Cape Town, 2001), informed by interviews with leading Generals. The same holds true for M. Malan, My Life with the SADF (Pretoria, 2006) and, remarkably, Truth and Reconciliation Commission - TRC Reports - The Report Of The Truth And Reconciliation Commission - Volume 2 Chapter 2: The State outside South Africa between 1960 and 1990, available at http://www.nelsonmandela.org/omalley/ index.php/site/q/031v02167/04lv02264/051v02335/061v02357/071v02372/081v02374.htm paras-163-173. There are brief mentions, almost wholly lacking in detail in M. Evans, 'The Frontline States, South Africa and Southern African Security: Military Prospects and Perspectives', Zambezia, xii (1984/5); P. Correia and G. Verhoef, 'Portugal and South Africa: Close Allies or Unwilling Partners in Southern Africa During the Cold War?' Scientia Militaria : South African Journal of Military Studies, xxxvii (2009), 50-72; J. R. T. Wood, A Matter of Weeks Rather Than Months: The Impasse Between Harold Wilson and Ian Smith - Sanctions, Aborted Settlements and War - 1965-1969 (Victoria, B.C., 2008); and J. Miller, 'Things Fall Apart: South Africa and the Collapse of the Portuguese Empire, 1973-74', Cold War History, xii, no. 2 (2012), 1-22. Only A. Afonso and C. de Matos Gomes, Os anos da guerra colonial, 1961-1975 (Matosinhos, 2010) have printed extracts from some of the ATLC meetings, with no indications of their provenance. Significant recent releases in South African Defence Force Archives and Portuguese Archives have only now allowed a detailed piecing together of the workings of ALCORA.

5. The cold-war context is best approached in O. A. Westad, The Global Cold War, (Cambridge, 2005), 207-18. See also M. Latham, 'The Cold War in the Third World', 258-80 in O. A. Westad and M. Leffler, The Cambridge History of the Cold War Vol. II, (Cambridge, 2010) and P. Glejeses, Conflicting Missions (Galago, 2003), passim.

6. See M. A. El-Khawas and B. Cohen, The Kissinger Study of Southern Africa: National Security Study Memorandum 39 (Secret) (Westport, 1976) and A. Lake, The 'Tar Baby' Option: American Policy Toward Southern Rhodesia (New York, 1976). SA Police Brigadier Venter's comments about changed US attitude are in [Lisbon, Arquivo] P[olícia Internacional e de] D[efesa do] E[stado/] D[irecçao] G[eral de] S[egurança], PR CI (2) N. 6431, Pasta 14, 'Reunião dos representantes das polícias da RAS, Rodésia e PIDE, Salisbury, 21-22 de Janeiro de 1970'. The 'Tar Baby' policy's impact on relations between the United States and the white-run states was not as great as was thought at the time. See E. Morgan, 'Our Own Interests: Nixon, South Africa, and Dissent at Home and Abroad', Diplomacy and Statecraft, vxii (2006), 475-95.

7. However, the Heath Government lost interest as the political cost became clear and restricted the lifting of the embargo to maritime equipment. M. Lipton, 'British Arms for South Africa', World Today, xxvi (1970), 427-34.

8. See notably P. A. Oliveira, Os Despojos da Aliança. A Grã-Bretanha e a Questão Colonial Portuguesa, 1945-75 (Lisbon, 2007) and N. MacQueen and P. A Oliveira, "Grocer Meets Butcher": Marcello Caetano's London Visit of 1973 and the Last Days of Portugal's Estado Novo', Cold War History, x (2010), 29-50.

9. L. White, "Normal Political Activities": Rhodesia, the Pearce Commission, and the African National Council', The Journal of African History, lii (2011), 321-40.

10. See Glejeses, Conflicting Missions, 230-2.

11. In a 1969 interview in Buenos Aires, South Africa's Foreign Minister, Hilgard Muller, said that a South Atlantic pact between Brazil, Argentina, Uruguay, the United States, and South Africa was on the cards. A. Hurrell, 'The Politics of South Atlantic Security: A Survey of Proposals for a South Atlantic Treaty Organization', International Affairs, lix (1983), 179-93, 180. General Fraser told the Rhodesians in March 1969 that South Africa was involved in forging a maritime alliance involving a number of countries in the Southern hemisphere, to be backed by the North Atlantic Treaty Organization (NATO) 
powers. Brief for the Prime Minister', Defence, 'Top Secret', Undated but documents contained within suggest March 1969, [Grahamstown, South Africa: Cory Library, Rhodes University] I[an] S[mith] P[apers], Deposit of 16 April 2010, box 12, File 'Relations with other countries 1 Jan. 1966 to 31 Dec. 1970'.

12. On the Soviet naval build-up, see Bruce D. Porter, The USSR in Third World Conflicts: Soviet Arms and Diplomacy in Local Wars, 1945-1980 (Cambridge, 1984), 36-59.

13. Muller, the South African Foreign Minister, made plain that this was the key motivation of the outward strategy: 'We must simply accept that our relations with the rest of the world are largely determined by our relations with African states.' Cited in J. E. Spence, The Strategic Significance of Southern Africa (London, 1970), 34.

14. See S. F. Jackson, 'China's Third World Foreign Policy: The Case of Angola and Mozambique, 1961-93', China Quarterly, cxlii (1995), 388-422.

15. C. Andrew and V. N. Mitrochin. The Mitrokhin Archive II, The KGB and the World (London, 2005), 443.

16. Westad, The Global Cold War, 214-15.

17. Westad, The Global Cold War, 215.

18. E. A. Kolodziej, 'France and the Arms Trade', International Affairs, lvi (1980), 54-72, $60-1$.

19. J. Cann, 'The Artful Use of National Power: Portuguese Angola (1961-1974)', Small Wars \& Insurgencies, xxii (2011), 196-225.

20. The full list of ATLC meetings is as follows: Pretoria, March-April 1971; Lisbon, November 1971; Pretoria, June 1972; Lisbon, November 1972; Pretoria, June 1973; Salisbury, November 1973; Pretoria, June 1974; Lisbon, October 1974. Minutes of the meetings are available at [Lisbon,] A[rquivo] H[istórico] M[ilitar], ADN, and SANDFA.

21. The schedules of the meetings were agreed at political level. See, for example, ADN, SGDN, U.I. 4385, letter, General João de Paiva Brandão (Vice-Chief of Staff of the Portuguese Armed Forces) to Lt. General K.R. Coster, Chief of General Staff, Rhodesia, 20 April 1971.

22. What such a conventional attack might look like was the source of much speculation in ALCORA circles. See ADN SGDN UI 4387, 'Setting for Paper Exercise: The Threat to the ALCORA Territories as on 1 Oct. 1973', produced in November 1972, for an example of how the threat was envisaged. One issue that attracted much attention at the time was the possibility of an OAU army, for use against remaining colonial powers. On 4 January 1972, the PIDE/DGS reported on a meeting of the OAU's Defence Commission, whose agenda was dominated by a single item: the study of a joint military high command. APIDE/DGSL, S[ecção] C[entral] 4277 CI(2), Informação n.8 - C.I (2).

23. ADN, SGDN UI 4385, 'Minutes of Discussions of the First Meeting of the Coordinating Committee held in Lisbon from 10 to 12 May 1971'.

24. AHM 7/B/44 Caixa 375 (54), PASC/11, 'A ameaça psicológica contra os Territórios ALCORA', received by the Estado Maior do Exército on 28 April 1972.

25. The 'psychological threat' was discussed at the $4^{\text {th }}$ ATLC meeting, held in Lisbon, in November 1972. The creation of a permanent organisation to deal with this threat was vetoed by the Portuguese, who claimed not to possess the necessary means. AHM 7/B/44 Caixa 371 (29), 'Comissão de Alto Nível ALCORA (ATLC), Acta da Quarta Reunião', Lisbon, 23 Nov. 1972.

26. ADN, SGDN U.I. 5574, 'CCSC/9 Exercício ALCORA. Sistemas de Cooperação Inter Forças Armadas ALCORA, 1972'.

27. ADN SGDN UI 4385, 'Elaboration of Agenda Items'.

28. ADN SGDN UI 5574, 'Exercise ALCORA. Third Meeting of Sub-Committees. APSC. 12 to 21 July. Minutes of Meeting', Pretoria, 21 July 1972.

29. This document then went on to detail the APSC's view of the existing and future threat (despite the lack of ISC information on the matter) and the ALCORA countries' needs in relation to the task of countering such a threat. General S. Cardoso's Angola: Anatomia de uma Tragédia (Lisbon, 2000), exemplifies the Portuguese Air Force's greater commitment to the conflict.

30. A fuller account of this evolution can be found in ADN UI 5570 'Exercício ALCORA. Subcomissão de Informações. Documento de Trabalho para a Reunião de 4 a 14 de Julho de 1972 em Lisboa', 31 May 1972. 
31. AHM 7/B/44 Caixa 371 (29), ATLC/4, 'Actas da Terceira Reunião da Comissão de Alto Nível ALCORA (13 a 15 JUN 1972)’, 15 June 1972.

32. All was not well, however. Under an ATLC directive issued in November 1973, the monthly intelligence reviews were rebranded 'ALCORA Periodic Intelligence Reviews'. Their contents were meant to cover enemy activity (including 'all aspects of development, not only in respect of terrorists but also African States and international organisations'), ALCORA activities, 'information on special studies', and 'interim changes to the threat'. But the first such bulletin, 1/74, dated 28 February 1974, was incomplete, since 'no intelligence reports have been received from Angola and Mocambique [sic]'. See ADN, SGDN UI 5573.

33. See Jackson, 'China's Third World Foreign Policy', 402-3.

34. The $4^{\text {th }}$ ACOC and ATLC meetings were, unsurprisingly, unimpressed by ISC/3, judging it to be impractical. It should have answered, the members agreed, four basic questions: what was the enemy doing presently; what it would do in the medium and long-term future; where the enemy might act; and, finally, where and how he would do so. AHM 7/ B/44 Caixa 372 (44), ACOC 5, 'Exercício ALCORA: Acta da 4ª Reunião da Comissão de Coordenação ALCORA que teve lugar em Pretória de 16 a 20 de Outubro de 1972' and AHM 7/B/44 Caixa 371 (29), 'Comissão de Alto Nível ALCORA (ATLC), Acta da $4^{\mathrm{a}}$ Reunião, Lisboa, 23 de Novembro de 1972'.

35. ADN, Fundo 3, Série 25, UI 58, round-robin letter from General João de Paiva de Faria Leite Brandão, 12 Dec. 1972. Includes the document in question, Annex C to ATLC/8.

36. ADN SGDN UI 5588, ISC/27, 'Actas da $5^{\text {a }}$ Reunião da Sub-Comissão de Informações Realizada em Salisbury de 02 a 16 de Fevereiro de 1973'.

37. These complaints would be repeated at the sixth ISC meeting in Pretoria, July 1973, which noted 'the lack of the adequate system of lateral links required to obtain intelligence regarding the ALCORA territories'. This problem, it was further noted, was being exacerbated by the delays involved with the PCC. ADN 7/B/44 Caixa 374 (55), 'ISC/30 Acta da Sexta Reunião da Subcomissão de Informações ALCORA Realizada em Pretória de 11 de Julho 1973 a 17 de Julho 1973'.

38. ADN UI 5588, AOSC/4, 'Minutes of a Meeting of the Air Planning Subcommittee, Salisbury, 12/16/February, 1973'.

39. ADN SGDN UI 4385, 'Setting for Paper Exercise'.

40. AHM 7/B/144 Caixa 374 (51) ACOC/9 'Comissão de Coordenação ALCORA, Acta da $5^{\text {a }}$ Reunião de 7 a 17 de Maio de 1973', Annex A, 'Proposta para a criação do EstadoMaior Combinado de Planeamento ALCORA (CAPS)'.

41. Lieutenant General G. P. Walls, leader of the Rhodesian delegation, affirmed his government's acceptance in principle of the PAPO scheme, adding 'that the Rhodesians were very grateful and by touched South Africa's invitation, which they would accept'. There was nothing new in the official running in relation to ALCORA being made by South Africa and Portugal, whose very existence was not called into question by the international community. AHM 7/B/44 Caixa 374 (51), ATLC/9, 'Exercício ALCORA. Acta da $5^{\mathrm{a}}$ Reunião da Comissão de Alto Nível ALCORA, em Pretória, de 18 a 21 de Junho de 1973', 21 June 1973.

42. AHM 7/B/44 Caixa 374 (51), ATLC/9, 'Exercício ALCORA. Acta da 5' Reunião da Comissão de Alto Nível ALCORA, em Pretória, de 18 a 21 de Junho de 1973', 21 June 1973.

43. AHM 7/B/44 Caixa 375 (54), letter N. 516/AU, 17 Dec. 1973, General Francisco da Costa Gomes, Chief of Staff of the Armed Forces, to various military authorities.

44. AHM 7/B/44 Caixa 374 (51), ACOC/13, 'Comissão de Coordenação ALCORA. Acta da 6 ( $^{\mathrm{a}}$ Reunião, 22 a 26 de Outubro 1973', Salisbury, 26 Oct. 1973.

45. See, for example, General Kaúlza de Arriaga, The Portuguese Answer (London, 1973).

46. On Gordian Knot, see B. C. Reis and P. A. Oliveira, 'Cutting Heads or Winning Hearts: Late Colonial Portuguese Counterinsurgency and the Wiriyamu Massacre of 1972', Civil Wars, xiv (2012), 80-103, 86-93.

47. ISP, April 10 Deposit, box 15, 'Relations With Other Countries', Top Secret MD/P/11 10 January 1972 - to be opened only by Mr Ian Smith, The Odell committee The Tete district of Mozambique - 28 December 1971. For evidence of Rhodesian military activity in Tete prior to this report see the account in D. Martin and P. Johnson, The Struggle for Zimbabwe: The Chimurenga War (London, 1981), 3-6. 
48. Ibid.

49. Details of this action can be found in Terror in Tete: A Documentary Report of Portuguese Atrocities in Tete District, Mozambique, 1971-72 (London, 1973).

50. ADN, Fundo 3, Série 25, UI 57OCC/1 JPS/14, 'Minutes of a Meeting Between Representatives of the Operations Co-ordinating Committee and the $\mathrm{C}$ in $\mathrm{C}$ Mocambique held at Nampula on $4^{\text {th }}$ August, 1972, at 1640 Hours', 16 Aug. 1972.

51. 'Minutes of a Meeting. ..' A solution previously advanced by Kaúlza de Arriaga seems to have been accepted. The Rhodesians could intervene, once permission had been granted, in some areas deemed less politically sensitive; as the overall political situation improved, and the priests' trial ended, these areas could be extended eastwards. Hot pursuit remained viable, as before.

52. Ian Smith Papers, April 10 Deposit, box 15, 'Relations With Other Countries', letter, Ian Smith to Marcello Caetano, 21 Aug. 1972.

53. That Portugal's stock had fallen in Salisbury was clear to all. The DGS wrote the Commander-in-Chief in Angola recommending co-operation with a Rhodesian journalist, Phillipa Berlin, of the Rhodesia Herald, who wanted to travel to Angola and Mozambique. She had previously written about the Cahora Bassa project in what the secret police described as 'a serious and objective manner', and now required military authorisation for her projected trip. The Consulate in Salisbury and the DGS recommended that this be granted 'in the expectation that her writings might contribute to counter the impression, in certain Rhodesian circles, that we are in a militarily critical phase'. PIDE/DGS 11.03.BNI 1812, letter, DGS Angola to Chefe do Estado Maior do Comando Chefe das Forças Armadas em Angola, 19 Sep. 1972.

54. A detailed account of this visit - minus, unfortunately, the contents of the talks - can be found in ISP, April 10 Deposit, box 15, 'Relations With Other Countries'. The visit included a trip to Madeira. The unidentified author of the account, who accompanied Smith, noted 'the British Military Attache snooping around the grounds of the hotel'. Smith and Caetano met twice.

55. Reis and Oliveira, 'Cutting Heads or Winning Hearts', 95-8. The authors note: 'The actual workings of the "Alcora alliance" of the three Southern African powers resisting the tides of decolonization and majority rule is an understudied issue, only now beginning to be carefully explored - and this certainly will contribute to a better understanding of the wider context of Wiriyamu.' Ibid., 93.

56. See, for example, AHD, PAA 937, Telegram, Ministry of Foreign Affairs, Lisbon, to Salisbury Consulate, 109, 28 Dec. 1972, in which the consul is asked to request the Rhodesian authorities not to refer in their contacts with the press to joint RhodesianPortuguese military operations, "which might be interpreted as the formation of a racial block instead of the natural defensive activity along our borders against attacks from abroad'. Such a request should not be couched in terms that might hurt Rhodesian susceptibilities.

57. See A. Couto, Moçambique 1974: O fim do império e o nascimento da nação (Lisbon, 2011), 235-6.

58. A. Couto, Moçambique 1974, 245.

59. See Ian Smith Papers, April 10 Deposit, box 15, 'Relations With Other Countries', letter, W. M. Knox to Ian Smith, in which the Lisbon-based Knox informed the Rhodesian Prime Minister that he had spoken to Morais Cabral, of the leading Lisbon daily Diário de Noticias on the issue of a joint command. Morais Cabral stated in this conversation that General Francisco Costa Gomes, recently installed as Chief of Staff of the Armed Forces, would be in favour of such a scheme. Knox returned to this theme on 6 July 1973 in a Top Secret report to S. D. O'Donnell, Secretary for Foreign Affairs, writing that 'I am more than ever certain' that the plan had originated with Costa Gomes, who, he had learned, was 'extremely annoyed with General [Kaúlza de] Arriaga, who, to some extent, through making foolish boasting statements to the press, has put the Minister of Defence in a most invidious position'.

60. ADN, SGDN UI 6179, Ministro da Defesa Nacional, 'Visita do Sr K. Flower, Director da Organização Central de Informações da Rodésia (CIO)', 8 April 1974. Tellingly, Flower suggested that such a scheme, if presented by the Rhodesians, would interest South Africa, who, had already given support for an expansion of the Flechas, while 
reserving a decision on the Zambezi line until after their elections. Minister of Defence Silva Cunha replied that such a step would send out the wrong signal to everyone north of the line, and opposed the creation of parallel means of collaboration outside ALCORA.

61. SANDFA, ALCORA 6, ATLC/11, 'Minutes of the Seventh ATLC Meeting Held in Pretoria from 24 to 28 June 1974', Appendix A to Annex 1.

62. AHM/FO/7/B/44 Caixa 374 (51), 'Acta da $6^{\text {a }}$ Reunião da Comissão de Alto Nível, Salisbúria, 26 a 30 de Novembro de 1973’, 30 Nov. 1973.

63. In a subsequent interview, Costa Gomes explained his disagreement with the conduct of the war in Mozambique, saying: 'I had no influence (acção) over the Portuguese military units, because the real commander, especially of the ground troops, was the Minister of National Defence.' J. Freire Antunes, A Guerra de Africa 1961-1974 (Lisbon, 1996), i. 122.

64. ADN, Fundo 3, Série 25, Caixa 58, 'Relatório das conversações realizadas em L. Marques em 11JUL72, entre os Ministros da Defesa de Portugal e da República da África do Sul', 17 July 1972.

65. Central Foreign Policy Files, 1973-1976, Record Group 59, General Records of the Department of State, FM AMCONSUL LOURENCO MARQUES TO SECSTATE WASHDC 193311 May 1973. http://aad.archives.gov [Accessed 8 May 2012].

66. PIDE/DGS, Serviços Centrais Pr. CI(2) n.6341 (24), 'Reunião dos representantes das polícias da RAS, Rodésia e PIDE, Lisboa, 10-11 de Setembro de 1973'. Nevertheless, in August 1973 Max Hastings had reported for the Evening Standard on Rhodesian operations deep in Mozambique. According to Hastings, who had spent three weeks in Africa, 400 men, supported by helicopters, were rooting out 'terrorist' bases. Hastings noted the low opinion the Rhodesians had their Portuguese colleagues. A summary of this article was sent by the Portuguese Embassy in London to the Ministério dos Negócios Estrangeiros on 20 Aug. 1973. [Lisbon,] A[rquivo] H[histórico] D[iplomático], PAA 1322. Some days later South African Minister of Information Connie Mulder, speaking in Salisbury, stated that his country preferred the frontline of the war against terrorism to be the Zambezi and not the Limpopo; quoting Vorster, Mulder added 'we know what to do if our neighbour's house is on fire.' AHD, PAA 1322, telegram, Portuguese ConsulateGeneral, Salisbury, to the M[inistério dos] N[egócios] E[strangeiros], 31 Aug. 1973. On 2 September it was the Observer's turn to report from Mozambique on the presence, and violent conduct, of Rhodesian forces, thanks to correspondent David Martin, who had interviewed a FRELIMO commander, Jose Moyane. According to the article, the Rhodesians' aim was to depopulate western Tete district, turning its inhabitants into refugees somewhere else. The article is summarised in AHD, PAA, 1322, telegram, Portuguese Embassy, London, to MNE, 3 Sep. 1973.

67. AHM, FO/7/B/44 Caixa 374 (51), 'Acta da $6^{\mathrm{a}}$ Reunião'... In a recent interview to the Rhodesian Farmer, Ian Smith had claimed that the only cross-border operations were of the hot-pursuit variety. AHD, PAA, 1322, telegram, 24 Nov. 1973, Portuguese Consulate-General, in Salisbury, to MNE.

68. See Ian Smith Papers, April 10 Deposit, box 15, 'Relations With Other Countries', letter, W.M. Knox to Ian Smith and J. H. Howman, 22 Jan. 1973, detailing Knox's contacts with Franco Nogueira over the issue.

69. Ian Smith Papers, April 10 Deposit, box 15, 'Relations With Other Countries', letter, W. M. Knox to Marcello Caetano, 15 June 1973. Knox delivered the letter in person, but Caetano would not be drawn into a discussion of the contents. Ian Smith Papers, April 10 Deposit, box 15, 'Relations With Other Countries', report, W. M. Knox to S. D. O'Donnell, Secretary for Foreign Affairs, 19 June 1973.

70. Central Foreign Policy Files, 1973-1976, Record Group 59, General Records of the Department of State, FM AMEMBASSY LISBON TO SECSTATE WASHDC 7743, 20 March 1973. http://aad.archives.gov [Accessed 8 May 2012].

71. ADN, SGDN UI 5573, ISC Monthly Bulletin 3/73, 23 February 1973-23 March 1973.

72. Central Foreign Policy Files, 1973-1976, Record Group 59, General Records of the Department of State, FM AMEMBASSY LISBON TO SECSTATE WASHDC 8824, 4 December 1973. http://aad.archives.gov [Accessed 8 May 2012].

73. ADN, SGDN, UI 6207, letter, 11 March 1974, Silva Cunha to P. W. Botha. 
74. ADN, Fundo 3, Série 25, Caixa 57, 'Acordo do empréstimo de 150 milhões de rands firmado com a RAS', 18 Sep. 1975. The deal was alluded to in very vague terms by Silva Cunha in his interview with José Freire Antunes (January 1995), and published in the latter's A Guerra de Africa, 333-42.

75. [Pretoria] S[outh] A[frica] D[epartment of] F[oreign] A[ffairs] 1-14-1, vol. 9, letter, Ambassador in Lisbon to the Secretary for Foreign Affairs, 3 Jan. 1974.

76. SADFA 1-14-1, vol. 9, letter, Ambassador in Lisbon to the Secretary for Foreign Affairs, 14 Feb. 1974.

77. Caetano's speech was a rousing call to arms in defence of overseas Portugal and the line being followed by the Government. He never mentioned Spínola by name, but the general was clearly very much in his thoughts. The South African Ambassador explained that Caetano, under fire, was playing for time, since an outright dismissal of Spínola, who had the support of some $50 \%$ of the army, notably its younger officers, could provoke trouble, even a coup. SADFA 1-14-1, vol. 9, letter, Ambassador in Lisbon to the Secretary for Foreign Affairs, 7 March 1974.

78. Present in Pretoria were Brigadier Brito e Melo, Portugal's director at PAPO, Brigadier J. A. Pinheiro, Assistant to the Chief of the General Staff, Colonel Silva e Sousa, Assistant Director, Operations, PAPO, and the Secretary, Colonel Santos Costa, Secretary of the CCAU, the organisation within the Ministry of National Defence charged with handling ALCORA business. SANDFA, ALCORA 6, ATLC/11v.

79. There were seven Portuguese vacancies in the organisation, and three Rhodesian. SANDFA, ALCORA 6, ATLC/11..., Annex A.

80. SANDFA, ALCORA 6, ATLC/11...Annex B.

81. Article 11 of the cease-fire agreement stated: 'The Portuguese State and Armed Forces will take measures to prevent that their national subjects take part, individually or collectively, in activities of military collaboration with the Governments of the R.S.A. and Rhodesia.' 